\title{
DIE LOOP VAN DIE DINGE
}

By hierdie geleentheid, terwyl ons die oorgang deurmaak na 1959, wil ek afsien van die voortgang van die koue oorlog in die buitewêreld, en ook van dic eeu. fees van die Gereformeerde Kerk in Suid-Afrika, en die aandag rig op die politieke toekoms van Suid-Afrika soos voorafgeskadu deur dinge wat reeds plaasgevind het, waarvan die mees moedgewende is die optrede tot nog toe van sy ed. dr. H. F. Verwoerd as Eerste Minister.

Nie alleen egter daarom nie kan verwag word dat 1959 belangrike ontwikkelinge sal inlui. Ander redes vir hierdie verwagting is dat teen die end van die jaar die provinsiale verkiesinge sal plaasvind, wat waarsky'nlik die nekslag sal gee aan die Verenigde Party, en dat daarna volg die half-eeu-jubileum van Unifikasie. Verder is dit interessant om daarop te let dat 'n kwart-eeu gelede die soewereiniteit van Suid-Afrika beklink is deur die statuswet.

Wat staan ons dan van nou af waarskynlik te wagte?

Allereers die grondvesting van die Republiek deur verkiesing van 'n staatshoof as president en 'n politieke vereniging van blank Suid-Afrika langs die weg van 'n koalisie-regering onder leiding van die Nasionale Party.

Daarna belangrike staatlrundige hervorminge en ekonomiese ontwikkelinge wat die republikeinse idec in sy volheid sal beliggaam, gepaard met oorskakeling van die Statebond tot 'n meer aangewese buitelandse omraming.
Tegelykertyd sal die Republiek van Suid-Afrika deur versnelde immigrasie en die beleid van afsonderlike en eiesoortige nasionale ontwikkeling van die onderskeie rasgroepe van Suidelike Afrika vinnig ontwikkel tot 'n oorwegend blanke staat, en die leiding neem tot die skepping van 'n Bondstaat van Suidelike Afrika, waarin verenig sal wees saam met die Republiek: SuidWes-Afrika, Rhodesië, Betsjoeanaland, Basoetoland, Transkei en ZoeloelandSwasieland.

Intussen sal die Republiek ook reeds die leiding begin oorneem het in Afrika suid van die Sahara tot bevryding en ontwikkeling van al sy volke teenoor die Westers-geïnspireerde imperialisme vanuit Noord-Wes-Afrika en die Oostersgeinspireerde imperialisme vanuit Noord-Oos-Afrika.

As hy hierby die steun kan verkry van Amerika, Engeland, Frankryk, België, Portugal, Italië, Duitsland en Israel, kan hy moontlik saam met hulle die Pan-Afrikaanse verbond ontwikkel wat die plek kan neem van die Statebond, wat Afrika betref.

Indien nie, deurdat sommige die emansipasie te vinnig wil laat plaasvind en andere te stadig, sou hy moet konsentreer op 'n meer selektiewe internasionale samewerking. En dan sal die nadruk gelê word op Engeland, België en Amerika.

In hierdie geval sal, naas die bevryding en ontwikkeling van die nie-blankes, gewaarborg word sowel die handhawing van die opkomende blanke nasies 
van Sentraal-Afrika as die vorming van Skriftuurlike Bantoe-kerke. Internasionale saamwerking sal egter as fundamentele voorwaarde steeds hê vervanging van veelrassigheid as grondslag vir toekomstige staatsvorming deur die beginsel van nasionale saamhorigheid.

In elk geval sal teen hierdie tyd in Sentraal-Afrika, insluitende Madagaskar, handel, nywerheid en onderwys onder leiding staan van Afrikaners en „Africans".

Kan geen saamwerking op die gewenste grondslag met die blanke buiteland verkry word nie, dan sal selfs teruggeval word op 'n uitsluitlike verbond tussen Afrikaners en "Africans", d.w.s. onderskeidelik die blanke en nieblanke nasionaliste van Afrika.

Trouens reeds by die vestiging van die republiek sal as grondslag van sy vriendskap met die buiteland neergelê word die ontwikkeling en handhawing van alle lewensvatbare blanke en nieblanke nasies in Afrika, in onderlinge samewerking.

Sodra as die koue oorlog dan in 'n warm oorlog oorgegaan het, sal hierdie beleid meebring dat die Republiek van Suid-Afrika in elk geval sal kan reken op die steun van die potensiële immigrantestroom uit Wes-Europa na die potensiële blanke ruggraat van Afrika van die Kaap tot by die $\mathrm{Nyl}$.

Dit alles hang egter daarvan af of die Afrikaners die „Africans” sal kan oortuig met woorde en dade dat daar in Afrika plek is vir altwee, maar dan ook net vir hulle alleen.

Hierdie oortuigingswerk sal aan die eenkant vereis 'n besonder vinnige ont- wikkeling van die prinsipiële universelisme in die nasionalisme van die Afrikanerdom en aan die ander kant die ervaring deur die nasionalisme van „Africans" dat veelrassigheid vir hulle moet uitloop òf op bestendiging van vreemde oorheersing vanuit die Weste of op die invoering van vreemde oorheersing van uit die Ooste.

Moontlik sal Engeland en Amerika teen daardie tyd ook al geleer het dat 'n nasionaal gedifferensieerde Afrika met insluiting van blanke nasionale state in sy hoogland-ruggraat vir die Weste meer betroubaar sal wees as 'n rasgemengde Afrika.

In elk geval gaan ons nou haas 'n beslissende halfeeu in, en wel van die wêreldkeuse tussen vryheid deur nasionale verskeidenheid of uniformiteit deur rasgemengdheid.

L. J. DU PLESSIS. 